\title{
The Statistical Analysis of the Transaction Volume of Peer-to- Peer Lending in China
}

\author{
Yingdong Wang ${ }^{1}$, Yanbin Zhang ${ }^{1}$, Xinru Xu ${ }^{1}$, Xiaoyan Yang ${ }^{1}$, Yueming Zheng ${ }^{1 *}$ \\ ${ }^{1}$ College of Literature Law \& Economics Wuhan University of Science \& Technology Wuhan, China
}

\begin{abstract}
Since 2013, China's P2P lending industry has developed rapidly, but many related problems have been exposed. Following the regulation of the P2P lending industry, the transaction volume of the P2P lending declines significantly. In order to study the development trend of China's P2P lending industry, based on the monthly data of China's P2P lending transaction volume from January 2014 to December 2019, the regression method was used to make seasonal adjustment. Then the Newey-west estimation method was used to make regression to establish the P2P lending transaction volume model in China. After analysis, it is concluded that the structure of China's P2P lending industry changed in 2017, and the volume of P2P lending industry will continue to decline in the future. Therefore, China's P2P lending industry not only needs to strengthen the supervision system of Internet credit, but also needs to promote Internet credit innovation and develop Internet credit technology and business model.
\end{abstract}

\section{Introduction}

Since 2013, Peer-to-Peer lending (P2P lending), as a new financial business model, has developed rapidly. It is characterized by low cost, low threshold, universal benefits and convenience, opening up a new financing channel for small and micro enterprises and individual investors. At the same time, P2P lending is also facing a series of problems. First, low default cost leads to high credit risk, frequent illegal fund-raising, and increased default risk. Second, the platform information disclosure is insufficient and information asymmetry [1]. Third, the P2P lending market has an asymmetric effect, which intensifies financial fragility [2].

P2P lending refers to online credit companies using online platforms to promote both parties to reach a deal through free bidding and collect service fees, while the borrower gains interest income but needs to bear corresponding risks at the same time [3]. P2P lending first started in the UK, then gradually emerged in European and American countries, and was introduced to China in 2007. China's P2P lending industry has also experienced a rapid growth before being regulated by the administration. Since 2017, the government has continuously strengthened the supervision of the P2P lending industry and raised the entry threshold of the $\mathrm{P} 2 \mathrm{P}$ lending industry. The $\mathrm{P} 2 \mathrm{P}$ lending industry is also facing the most difficult moment. By analyzing the monthly transaction data of China's P2P lending industry from 2014 to 2019, this paper establishes a trading volume model of China's P2P lending industry and analyzes the development trend of China's P2P lending industry, and puts forward relevant policy suggestions.

\section{Overview of Development Process}

The period from 2007 to 2012 was the initial development period of China's P2P lending industry. At this stage, $\mathrm{P} 2 \mathrm{P}$ lending platforms were mainly credit loans, and the number of active $\mathrm{P} 2 \mathrm{P}$ lending platforms was very small. Since then, P2P lending platforms in China have exploded. Since 2013, P2P and other P2P lending forms have emerged in social and economic life. In essence, P2P was a medium for information communication between borrowers and borrowers. Its emergence broke the limitations of traditional capital circulation. Compared with the advantaged advantages of large and medium-sized enterprises in the credit system, it opened up a new financing channel for young entrepreneurs, small and micro enterprises and other objects with capital needs, greatly expanded the transaction space and time cycle. However, along with the development of the wave of P2P lending, there were also a series of problems such as carried money to run, capital chain break, and so on, which have been widely valued by the society [4]. In 2017, the government required local governments to complete the registration of major online lenders within their jurisdiction by the end of April 2018. At the same time, the government had made further explanations on key issues such as the transfer of creditor's rights, the provision of risk reserves

*Corresponding author's e-mail: wenfaxueyuan18@163.com 
and the deposit and management of funds. [5]. Under the background of continuous improvement of regulatory rules, the transparency construction of the P2P lending industry was obviously unable to cope with this, and there was a general phenomenon of retreat. Therefore, the P2P lending industry seems to enter an ice age and the major data indicators began to show a gradient decline.

In 2018, the state issued relevant regulations, pointing out that lending platforms, banks and other financial institutions officially entered the national system and were supervised by the Internet financial management department, thus P2P officially became the regular army of the financial industry. However, in 2019, with the hope of filing for most enterprises in P2P lending industry increasingly fading, in order to rectify the order of the financial market, the government began to try to promote the clearing or benign withdrawal of the bad P2P lending platforms [6]. On the one hand, for some normal operating institutions of a certain scale that were strictly compliant, we should encourage the transformation through policy induction and improve the competitiveness of the company by means of "three liters and two drops". The "three liters" mainly referred to the improvement of efficiency, experience and scale, while the" two drops" mainly included the reduction of cost and risk. The key to the realization of "good currency drives out bad currency" was to focus on these five elements. On the other hand, for institutions facing the credit crunch, the attitude was to retreat, so the lending industry undoubtedly ushered in a "great purge". Finally, the remaining $\mathrm{P} 2 \mathrm{P}$ lending agencies, small loan companies and lending agencies would become the main transformation direction of the government [7-9].

According to the transaction books of China's P2P lending industry from 2014 to 2019 , as shown in TABLE $\mathrm{I}$, the transaction volume of P2P lending from 2014 to 2019 showed an increasing trend before decreasing, and the total transaction volume of P2P lending reached the peak in 2016, then the total transaction volume of P2P lending significantly decreased. However, the comprehensive reference rate of P2P lending was still increasing, and the average loan term gradually reduced from 15.39 months to 5.85 months, which was about one third of the original. From the current state, the development of P2P lending industry in China is not optimistic and has entered a bottleneck period. Only by solving the existing problems of P2P lending industry can the former vitality of $\mathrm{P} 2 \mathrm{P}$ lending industry be restored.

TABLE I. TRANSACTION DATA OF CHINA'S P2P LENDING INDUSTRY

\begin{tabular}{llll}
\hline Year & $\begin{array}{l}\text { Total transaction } \\
\text { volume (RMB 100 } \\
\text { million) }\end{array}$ & $\begin{array}{l}\text { Comprehensiv } \\
\text { e reference } \\
\text { rate (\%) }\end{array}$ & $\begin{array}{l}\text { Average } \\
\text { borrowing } \\
\text { term } \\
\text { (Month) }\end{array}$ \\
\hline 2014 & 9645 & $9.84 \%$ & 15.39 \\
2015 & 17948 & $9.87 \%$ & 13.04 \\
2016 & 28048 & $9.45 \%$ & 9.16 \\
2017 & 20636 & $10.62 \%$ & 7.78
\end{tabular}

\begin{tabular}{cccc}
2018 & 9823 & $13.81 \%$ & 6.80 \\
2019 & 2528 & $18.50 \%$ & 5.85 \\
Mean & 14772 & $12.01 \%$ & 9.67 \\
\hline
\end{tabular}

\section{Empirical Research}

\subsection{Data Description and Processing}

The research data in this paper are the monthly data of P2P lending transaction volume in China from January 2014 to December 2019. The data come from the home of online loan. Let the monthly P2P lending transaction volume in China be $y$ billion yuan. Since the data are monthly data, the monthly P2P lending transaction amount after seasonal adjustment is $y_{2}$ billion yuan through seasonal adjustment by regression method, and the sensitivity of data difference is reduced by taking logarithm. As shown in Fig. 1, the seasonally adjusted sequences become smoother. Then, the treated sequence $\ln y_{2}$ was tested for stationarity, and $\ln y_{2}$ is the nonstationary sequence. Further verification shows that the first-order difference of $\ln y_{2}$ is a stationary sequence, so it is modeled.

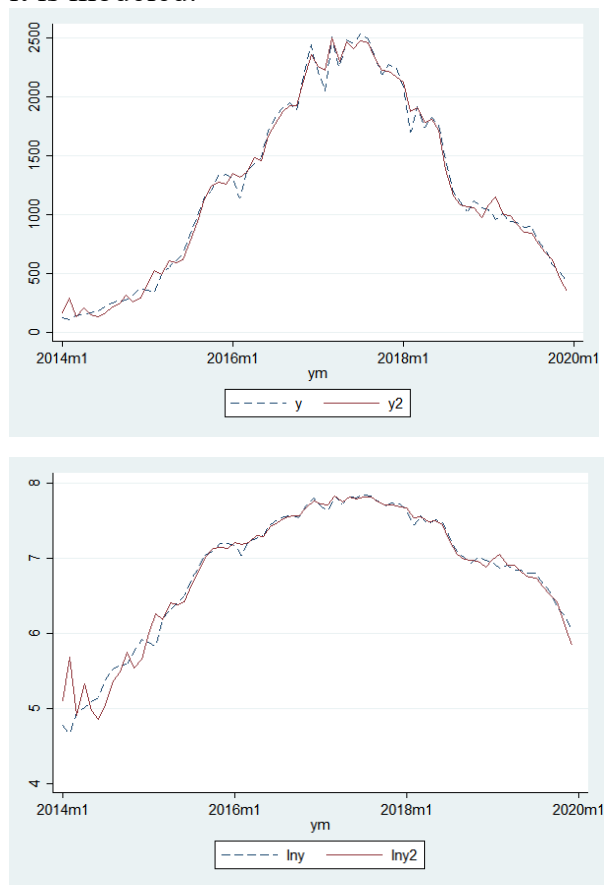

Figure 1. Line charts of sequences before and after seasonal adjustment

\subsection{Model setup and estimation}

In this paper, Autoregressive Process of order 1 (AR(1)) is adopted, that is, the future value of $y_{t}$ is predicted by the past value of $y_{t-1}$.

$y_{t}=\beta_{0}+\beta_{1} y_{t-1}+\varepsilon_{t} \quad(t=2, \ldots, T)$ 
It can be seen from Fig. 1 that the monthly P2P lending transaction amount in China shows a trend of increasing first and then decreasing, and the turning point is about January 2017. Therefore, it is necessary to consider whether there is a structural break in the monthly P2P lending transaction amount in China. Let's introduce the dummy variable $D t$, and before January 2017, $D t=0$; After January 2017, $D t=1$. There are two cases to consider when introducing dummy variables. In the first case, only the dummy variable itself is introduced.

$$
y_{t}=\beta_{0}+\beta_{1} y_{t-1}+\gamma D_{t}+\varepsilon_{t} \quad(t=2, \ldots, T)
$$

The second case is that when the dummy variable $D_{t}$ is introduced, the interaction term $D_{t} y_{t-1}$ between the dummy variable $D_{t}$ and the explanatory variable $y_{t-1}$ is introduced.

$$
y_{t}=\beta_{0}+\beta_{1} y_{t-1}+\gamma D_{t}+\delta D_{t} y_{t-1}+\varepsilon_{t} \quad(t=2, \ldots, T)
$$

Let's substitute the first-order difference of $\ln y_{2}$ into (3).

$$
\begin{array}{r}
\square \operatorname{lny}_{2 t}=\beta_{0}+\beta_{1} \square \operatorname{lny}_{2 t-1}+\gamma D_{t}+\delta D_{t} \square \operatorname{lny}_{2 t-1}+\varepsilon_{t} \\
(t=2, \ldots, T) \quad \text { (4) }
\end{array}
$$

In order to ensure the correctness of regression, heteroscedasticity and autocorrelation tests were performed. Starting with White's test, the $\mathrm{P}$ value is 0.0000 , under the level of $1 \%$ strongly reject $\mathrm{H} 0$ : homoskedasticity. Then Breusch-Godfrey LM test, the results show that the $\mathrm{P}$ value is 0.0000 , under the level of $1 \%$ strongly reject $\mathrm{H} 0$ : no serial correlation. Therefore, Heteroscedasticity and Autocorrelation Consistent Standard Error should be used. The Newey-West regression is performed and the results are shown in TABLE II.

TABLE II. REGRESSION RESULTS

\begin{tabular}{lccccc}
\hline$\square \operatorname{lny}_{2}$ & Coef. & St.Err. & $\boldsymbol{t}$-value & $\begin{array}{l}\boldsymbol{p} \text { - } \\
\text { value }\end{array}$ & Sig \\
\hline$\square \ln _{2 t-1}$ & -0.453 & 0.204 & -2.22 & 0.030 & $* *$ \\
$D_{t}$ & -0.134 & 0.032 & -4.18 & 0.000 & $* * *$ \\
$D_{t} \square \operatorname{lny}_{2 t-1}$ & 0.792 & 0.283 & 2.79 & 0.007 & $* * *$ \\
Constant & 0.096 & 0.030 & 3.15 & 0.002 & $* * *$ \\
\hline Meandependentvar & 0.002 & SDdependentvar & 0.172 \\
Numberofobs & 70.000 & F-test & 11.989 \\
\hline \multicolumn{5}{r}{$* * * \mathrm{p}<0.01, * * \mathrm{p}<0.05, * \mathrm{p}<0.1$} \\
\hline
\end{tabular}

According to the regression results, $\mathrm{F}$ value is 11.989 , and the overall significance of the equation is good. The estimated coefficient of the variable is -0.453 and the $P$ value is 0.030 , which is statistically significant at the level of $5 \%$. It can be seen that the change in the volume elasticity of $\mathrm{P} 2 \mathrm{P}$ lending in the previous period will have an impact on the change in the volume elasticity of P2P lending in the current period. Secondly, the estimated coefficient value of the variable is -0.134 , and the $\mathrm{P}$ value is 0.000 , which is significant at the level of $1 \%$. It can be seen that there is a structural break in China's P2P lending industry in 2017. Finally, the estimated coefficient of the interaction term is 0.792 and the $\mathrm{P}$ value is 0.007 , which is significant at the $1 \%$ level. Therefore, the structural break in 2017 has a great impact on the elasticity of P2P lending transaction volume.

It can be concluded that the trading volume equation of China P2P lending is as follows:

$$
\square \operatorname{lny}_{2 t}=-0.453 \square \operatorname{lny}_{2 t-1}-0.134 D_{t}+\emptyset .792 D_{t}^{\square} \operatorname{lng}_{2 t-1}+0.096(5)
$$

Further, (6) and (7) can be concluded.

$$
\square \ln _{2 t}=-0.453 \square \ln y_{2 t-1}+0.096 \quad \text { (Before Jan. }
$$$$
\text { 2017) (6) }
$$

$$
\begin{aligned}
& \square \operatorname{lny}_{2 t}=0.339 \square \operatorname{lng}_{2 t-1}-0.038 \quad \text { (After Jan. } \\
& 2017 \text { ) (7) }
\end{aligned}
$$

Before Jan. 2017, the coefficient of the variable $\square \operatorname{lny}_{2 t-1}$ is estimated to be -0.453 , so the change in the transaction volume elasticity of $\mathrm{P} 2 \mathrm{P}$ lending in the previous period has a negative effect on the change in the transaction volume elasticity of $\mathrm{P} 2 \mathrm{P}$ lending in the current period. At this point, the $\mathrm{P} 2 \mathrm{P}$ lending volume is an increasing trend, but the growth trend of $\mathrm{P} 2 \mathrm{P}$ lending volume will continue to weaken. After January 2017, the coefficient of the variable $\square \operatorname{lny}_{2 t-1}$ is estimated to be 0.039 , which means that the change in the transaction volume elasticity of P2P lending in the previous period has a positive effect on the change in the transaction volume elasticity of P2P lending in the current period. After 2017, the transaction volume of P2P lending shows a declining trend. Through the P2P lending volume model of China, it can be predicted that the P2P lending volume of China will continue to decline in 2020, and the prospect of the P2P lending industry is not optimistic.

In order to further test whether there is structural break in the trading volume function of $\mathrm{P} 2 \mathrm{P}$ lending and to test the joint significance of $D_{t}$ and $D_{t} \square \operatorname{lng}_{2 t-1}$. The F statistic obtained is 15.91 , and the $\mathrm{P}$ value is 0.0000 , strongly rejecting the null hypothesis of "no structural break ". Therefore, there is a structural break in the transaction volume function of China's P2P lending.

\subsection{Robustness Check}

In order to ensure the robustness of the final regression results, four regression results are listed in table 3 . Result1 is the regression result of least square method and robust standard error for (1), where the statistical significance of variables is not strong. Result 2 is the regression result of least square method and robust standard error for (2) with dummy variables. The variables are relatively significant, while the dummy 
variables are extremely significant. Result3 is the regression result of the least square method and robust standard error for the (3) that introduces dummy variables and interaction terms. It can be seen that the interaction terms are very significant and the significance of the variables is enhanced. The Result4 is the result of Newey-West regression for (3). Compared with the coefficient estimated by Result3, the variables are more significant.

TABLE III. ROBUSTNESS CHECK

\begin{tabular}{lllll}
\hline & Result1 & Result2 & Result3 & Result4 \\
\hline$\square \operatorname{lny}_{2 t-1}$ & $-0.207^{\mathrm{a}}$ & $-0.349^{*}$ & $-0.453^{* *}$ & $-0.453^{* *}$ \\
& $(0.221)^{\mathrm{b}}$ & $(0.205)$ & $(0.220)$ & $(0.204)$ \\
$D_{t}$ & - & $-0.156^{* * *}$ & $-0.134^{* * *}$ & $-0.134^{* * *}$ \\
& & $(0.0306)$ & $(0.0311)$ & $(0.0321)$ \\
$D_{t} \square \operatorname{lny}_{2 t-1}$ & - & - & $0.792^{* * *}$ & $0.792^{* * *}$ \\
& - & - & $(0.279)$ & $(0.283)$ \\
Constant & 0.00534 & $0.0878^{* * *}$ & $0.0956^{* * *}$ & $0.0956^{* * *}$ \\
& $(0.0192)$ & $(0.0267)$ & $(0.0276)$ & $(0.0304)$ \\
\hline $\mathrm{N}$ & 70 & 70 & 70 & 70 \\
$\mathrm{R}^{2}$ & 0.048 & 0.236 & 0.307 & - \\
\hline
\end{tabular}

a. Estimated coefficient

b. Standard errors in parentheses

${ }^{* * *} \mathrm{p}<0.01,{ }^{* *} \mathrm{p}<0.05,{ }^{*} \mathrm{p}<0.1$

\section{Conclusions and Recommendations}

\subsection{Conclusions}

Through empirical analysis, it is found that before 2017, P2P lending grew rapidly with their unique advantages, but the growth rate gradually declined. In 2017, the adjustment of the Chinese government to the P2P lending industry and the introduction of relevant policies resulted in the structural break of the P2P lending industry in China. A large number of bad P2P lending platforms were eliminated, and the transaction volume of P2P lending dropped sharply. At the same time, the future P2P lending transaction volume will continue to decline, China's P2P lending industry development bottleneck.

\subsection{Recommendations}

For the healthy development of China's P2P lending industry, it is necessary to strengthen the supervision system of Internet credit and avoid many risks in the industry. At present, China's Internet credit industry has experienced a period of explosive growth, which also exposed many problems in the industry. Due to the low entry threshold and high openness of the Internet credit industry, information risk, credit risk and other financial risks are easy to appear in the market. Through the establishment of a special regulatory department and the improvement of the relevant regulatory system, financial risks in the market can be effectively reduced, which is conducive to the standardized, stable and safe development of Internet credit. In addition, it is necessary to encourage Internet credit innovation and develop Internet credit technology and business model. Internet credit can improve the information security of Internet credit through technical innovation, so as to launch a new financial business model. The innovation of the business model of Internet credit can satisfy the minority demand neglected in the financial market, expand the customer group and market share of Internet credit, and push Internet credit to a higher development stage.

\section{Acknowledgment}

Special thanks to the teachers of Wuhan University of Science \& Technology for their support. We would also like to thank the innovation and entrepreneurship training program for Chinese college students and the innovation and entrepreneurship fund for graduate students of Wuhan University of Science \& Technology. Project number 201910488002X and JCX201958.

This achievement is funded by the innovation and entrepreneurship training program for Chinese college students and the innovation and entrepreneurship fund for graduate students of Wuhan University of Science \& Technology. Project number 201910488002X and JCX201958.

\section{References}

[1] Y. Guo, J. Ying, and L. Zhang, "Guarantee machine system under the net loan investment Analysis and verification of the theory of behavior of sheep flock," Journal of Financial Development Research, pp.16-22, July 2019.

[2] Y. Ye, "Risks and countermeasures of P2P online lending platforms under the new situation-- on the compliant development of P2P platforms after the thunderstorm," Journal of Political Science and Law, vol.36, pp.120-128, August 2019.

[3] M. F. Lin, N. R. Prabhala, and S. Viswanathan , "Judging Borrowers by the Company They Keep: Friendship Networks and Information Asymmetry in Online Peerto-Peer Lending," Management Science, pp.17-35, 2013.

[4] J. Wang, and K. Gao, "P2P network loans to small and micro enterprises

Analysis of the impact of financing," Foreign Economic Relations \& Trade, vol.25, pp.85-87, September 2019.

[5] B. Yu, "The supervision and improvement of P2P network loans," Legal System and Society, pp.66-67, December 2019.

[6] Y. Du, "Research on risk control ecology of P2P network loan industry," China Collective Economy, vol.35, pp.74-77, December 2019.

[7] C. Deng, "A comparative study on the credit risk measurement model of P2P network lending -- take "Prosper" and "paipaidai" as an example," China Journal of Commerce, vol.28, pp.63-66, October 2019.

[8] J. Zhao, "Analysis on the difficulties and countermeasures of clearing P2P network lending institutions," Economic Forum, vol.26, pp.95-103, December 2019.

[9] X. Yu, and F. Sun, "The research on the long-term mechanism of perfecting the standardization development of P2P network loan industry in China in the post-regulation period -- an analysis from the perspective of institutional supply," Financial Theory \& Practice, vol.38, pp.40-47, 2019. 